\title{
THE STUDENT-NURSE PEDAGOGICAL RELATIONSHIP: A HERMENEUTIC-PHENOMENOLOGICAL STUDY ${ }^{1}$
}

\author{
Luz Nelly Rivera Alvarez², José Luís Medina Moya
}

\footnotetext{
${ }^{1}$ Associated research - Knowledge and reflective experience of the nursing student in their care practices. Doctoral thesis, 2013. Universitat de Barcelona. COLCIENCIAS: LASPAU, Call no. 419, expedient no. 20080404.

${ }^{2}$ Ph.D in Education and Society. Professor, Facultad de Enfermería, Universidad Nacional de Colombia. Bogotá, Colombia. E-mail: lnriveraa@unal.edu.co

${ }^{3}$ Ph.D in Philosophy and Educational Sciences. Professor, Pedagogy School. Department of Didactics and Educational Organization, Universitat de Barcelona. Barcelona, Spain. E-mail: jlmedina@ub.edu
}

\begin{abstract}
Objective: to research studied the meaning of the pedagogical relationship in the training of nursing student and characterizes the role that such a relationship in the practice of reflexive, relational and ethical care student.

Method: qualitative research with a Phenomenological-Hermeneutical approach Gadamer, ethnographic. Developed during the clinical practices of 11 students, with their respective teacher and clinical instructors in a School of Nursing of Barcelona, from February 2011 to February 2012. Strategies for data collection were: participant observation, informal conversation, in-depth interviews, and written materials. The data analysis used the method of constant comparisons of Glaser and Strauss.

Results: the pedagogical relationship "oriented towards the student" emerged as the thematic core, includes categories such as "being there for the student", "trust", and "autonomy".

Conclusions: the pedagogical relationship 'oriented towards the student' is a relationship of care that provides support, trust, presence, empowerment, and autonomy.

DESCRIPTORS: Education, nursing. Students, nursing. Faculty, nursing. Teaching. Professional competence.

\section{LA RELACIÓN PEDAGÓGICA ESTUDIANTE-ENFERMERA: UN ESTUDIO HERMENÉUTICO-FENOMENOLÓGICO}

\section{RESUMEN}

Objetivo: esta investigación estudió el significado de la relación pedagógico en la formación del estudio de enfermería y caracteriza el papel que esta relación posee en la práctica del cuidado, reflexiva, relacional y ética del estudiante.

Método: investigación cualitativa con abordaje hermenéutico fenomenológico de Gadamer, etnográfico. Desarrollado durante la pasantía clínica de 11 alumnos con su respectivo profesor e instructor clínico de una Escuela de Enfermería en Barcelona, entre febrero de 2011 y febrero de 2012. Las estrategias de recolección de datos fueron: observación participante, conversas informales, entrevistas a profundidad y materiales escritos. Para su análisis fue utilizado el método comparativo constante de Glasser y Strauss.

Resultados: la relación pedagógica orientada para el alumno emergió como el núcleo temático que incluyó categorías tales como "estar para el alumno", "confianza" y "autonomía".

Conclusión: la relación pedagógica orientada para el alumno es una relación de cuidado que ofrece acompañamiento, confianza, presencia, empoderamiento y autonomía.

DESCRIPTORES: Educación en enfermería. Estudiantes de enfermería. Docentes de enfermería. Enseñanza. Competencia profesional. 


\section{RELAÇÃO PEDAGÓGICA ESTUDANTE -ENFERMEIRO: UM ESTUDO HERMENÊUTICO-FENOMENOLÓGICO}

RESUMO

Objetivo: esta pesquisa estudou o significado da relação pedagógica na formação do estudante de enfermagem e caracteriza o papel que essa relação na prática do cuidado reflexiva, relacional e ética do estudante.

Método: pesquisa qualitativa com abordagem hermenêutica-fenomenológico de Gadamer, etnográfico. Desenvolvido durante o estágio clínico de 11 alunos, com seu respectivo professor e instrutores clínicos de uma Escola de Enfermagem em Barcelona, entre fevereiro de 2011 e fevereiro de 2012. As estratégias de coleta de dados foram: observação participante, conversas informais, entrevistas em profundidade e materiais escritos. Para análise dos dados foi utilizado o método de comparativo constante de Glaser e Strauss.

Resultados: a relação pedagógica 'orientada para o aluno' emergiu como o núcleo temático, inclui categorias tais como 'estar para o aluno', 'confiança' e 'autonomia'.

Conclusão: a relação pedagógica 'orientada para o aluno' é uma relação de cuidado que oferece acompanhamento, confiança, presença, empoderamento e autonomia.

DESCRITORES: Educação em enfermagem. Estudantes de enfermagem. Docentes de enfermagem. Ensino. Competência profissional.

\section{INTRODUCTION}

One of the main reforms nursing is going through in Spain is the adaptation of its studies to the European Higher Education Area (EHEA) by means of a four-year program (graduate) in which the practical training acquires a special importance (43\% of the total program). ${ }^{1}$ This revitalization of the clinical training practice is based on the broad consensus among the academic community about the practical nature of the knowledge that expert nurses use to identify and resolve the problems in their activity. ${ }^{2-3}$

Some authors claim that the practicum is the thread around which the entire curriculum of nursing is structured. Understanding the hospital practicum as a unknown terrain, uncertain and complex for a nursing student, in it, we risk losing the sense of one's competence, control, and self-confidence. ${ }^{5}$ This is a collective world, with its own blend of materials, tools, languages, and values, it influences the particular point of view, thought, and action that teachers and nurses have about themselves. ${ }^{5}$ It implies the students learn practically ${ }^{6}$ through exposure and immersion, conversations, and collaborative work with tutors and fellow nurses, acquiring a nearly autonomous art of clinical practice, the transactional link between classroom learning and practical experiential learning. ${ }^{7}$

As teachers of clinical practice, we agree with Shön, ${ }^{5}$ in relation to the importance of trust and intentionality in a pedagogical relationship between student and teacher or tutor nurse, taking also into account the individual's character in this relationship of the clinical practicum. Besides that, the practicum highlights the importance of establishing a humanized pedagogical relationship between student and tutor nurse with qualities such as completeness, vocation, concern and affection, sense of responsibility, moral intuition, openness, self-criticism, request maturity, common sense to the student's subjectivity, interpretive intelligence, pedagogical understanding of their needs and passion for knowledge..$^{8-10}$

When the pedagogical relationship is based on trust, mutual recognition and dialogue, the nurse cares for and welcomes the student as a professional and as a person, ${ }^{9}$ exposes his/her pedagogical actions according to the interests, concerns, and needs of the student, values a scrupulous respect for the student's autonomy, and has an interest in meeting and connecting with the student's experience. However, Bardallo, ${ }^{11}$ Solvoll e Heggen's ${ }^{12}$ findings show that the student's care experience and the role of their relationship with the tutor nurse are not questioned, due to the predominance of clinical training geared towards problem-solving and abstract theory.

Thus, the objectives of this work were to study the meaning of the pedagogical relationship in the student's education and to characterize the role of this relationship in the formation of a reflective, relational, and ethical care practice.

\section{METHODS}

This survey was conducted with a qualitative approach, adopting a phenomenological-hermeneutic, ${ }^{13-14}$ theoretical perspectives with a methodological approach of ethnographic cutoff. It is phenomenological due to concern about the nursing student's experience in their clinical practice as it is happening and their experience in a pre-reflective plan, neither classifying nor condensing it. ${ }^{13}$ Hermeneutics in the interpretation of the meanings that, in a sense, are implicit in the actions and clinical experience of the nursing student. ${ }^{14}$ The method- 
ological approach of an ethnographic cut-off point is based on the ontoepistemological assumption called eco-naturalist, an assumption that believes that human actions are partially determined by the context and environment in which they happen. In other words, that the practice of student care can only be studied by direct contact with the hospital reality where the practice occurs. ${ }^{15}$ We used a simple selection based on criteria to choose this study's participants. ${ }^{16}$ The field work was development in the disciplines "Hospital Practicum and Clinical States II", during the clinical practice of eleven students, their teacher and clinical tutors, who participated voluntarily in the study in a school of nursing in Barcelona and in a university hospital in Barcelona (Spain). In this context, the teacher is responsible for the clinical oversight of a group of six to eight students and the clinical tutor (nurse) is responsible for the practical training of a student. Data collection was developed during the period from February 2011 to February 2012 and employed the theoretical saturation criterion.

Information collection strategies were: participant observation, non-participant observation, informal conversation, in-depth interview, and document analysis (student's reflexive diaries, the discipline's curricular plan, and others).

Note: according to the theoretical perspective of the study, one of the methodological criteria was the intensive and long-term participation in the hospital environment with nurses and nursing students, where they develop their clinical practice. The study used participant and non-participant observation. The non-participant observation was held on the discipline's seminars, developed in a classroom of the nursing school, with the purpose of understanding directly the pedagogical action between students and teachers in a particular context. As researchers, our role was solely observation, to not distort the dynamics of the classroom. In total, 22 observations were carried out in the classroom, each session lasting 2 hours. We registered a total of 44 hours of observation.

Participant observation was developed in the clinical practice of nursing students until we achieved the theoretical saturation of information, ${ }^{17}$ meaning when we couldn't tell anything new in the observations and information of the participants. These practices had a daily hourly intensity of 7 hours, from Tuesday to Friday, 2:00 pm to 9:00 pm. The observation was carried out in three parts of hospitalization in a third-level university hospital. The duration of each note fluctuated between one and 5 hours per student and unit. There was a total of 95 hours of participant observation. We guaranteed ethical aspects such as privacy, autonomy and the veracity of the information.

Informal conversation: it is a colloquial interview conducted during the student's clinical practice observation. We used it to mobilize the student to reflect on the triggering clinical they had experienced and to deepen the meanings elaborated by those situations. These conversations had a flexible emerging character according to the clinical situations observed and provided clues to guide subsequent observations and semi-structured in-depth interviews. These conversations had a duration of approximately 30 to 45 minutes, were recorded on magnetic tape, transcribed, and sent for the student's validation. In total, there were ten colloquial interviews of this type: two colloquial interviews with the teacher supervising the practice; six colloquial interviews, one for each student; and two additional colloquial interviews with two of the students.

In-depth interviews: at the end of the clinical practice, we carried out in-depth interviews with each student (11 interviews with students, an interview with a nurse - considered as a key participant, and two interviews with the supervising teacher). The interviews' goal was to analyze and understand how much meaning the students and the tutor nurse attributed to the pedagogical situations observed. It was also the right time to request clarifications and qualifications regarding some of the interpretations that had taken place in informal conversations. All the interviews were recorded and transcribed literally. The average length of each was approximately 2 hours. The verbatim transcriptions were returned to the study's participants for their review and validation, whose notes focused on the question of style, not content. We guaranteed ethical aspects such as privacy and the veracity of the information.

Written materials: for example, reflective journals that students wrote during their clinical practice. Their goal was to motivate the student to reflect on issues and situations experienced in their clinical practice. Other written materials were the plans of care (PAEs) that were performed by the students. We requested those occasionally to clarify any aspect of the presentation of clinical situations. We also considered official documents: curriculum, discipline teacher's plan, and institutional regulations. And, finally, the researchers' field diaries.

To analyze the information there were the three moments of the constant comparisons method. 
We chose it because this method allows the development of conceptualizations in an inductive way and the development of conclusions and results in a systematic, consistent, plausible, and close to the data manner. ${ }^{17}$ In the first moment, we performed the open encoding (segmentation and encoding of units of meaning), which identified the categories. In the second we performed the axial coding where the categories were related to identifying the main themes or thematic nuclei, approaching a more conceptual level, to identify emerging thematic cores. Finally, in the third, we performed the selective encoding, which supplemented the descriptions and relationships between categories and thematic nuclei and identified central qualitative axes throughout the data's corpus. The comments, written materials, conversations and transcribed interviews were organized chronologically in the Atlas ti program version 6, which was used uniquely for the processes of data storing, coding, recovery, and reunification.

As criteria of methodological rigour, we chose: a) extended stay in the field and continued and persistent observation, where we sought, on the one hand, to achieve the highest quotas of naturalness and spontaneity in participants and, on the other, to maintain a long period of residence in the place where the study phenomena happened in order to be able to handle the pedagogical situations and understand the meanings attributed to them; $b$ ) triangulation (of methods, participants, and experts). The methods triangulation was implemented by combining the study's methodological strategies, which made it easy to capture in-depth the variability of the phenomena studied and to identify coincidences and contradictions in information. The research triangulation and the participant's triangulation were used to validate and contrast the researchers' interpretations with the participant's meanings and interpretations on the general sense of the results. The participants had the opportunity to read the complete transcript of the interviews and conversations and to validate or modify their content. This triangulation was achieved with the revision of the material collected by professional experts; and c) structural corroboration and benchmark adequacy of the results, referring to the structural consistency (internal consistency) of the results with the conceptual and methodological concerns of the research.

Regarding the ethical aspects, this study has been reviewed by the Research Ethics Committee of the University Hospital and approved on June $9^{\text {th }}, 2011$ (Record 11/11) with the no. PR144/11. We considered the ethical principles set out in the World Medical Association Declaration of Helsinki ${ }^{18}$ and the Organic Law of Personal Data Protection (LOPD) in its Title III. ${ }^{19}$ This way, we followed the ethical principles of autonomy, beneficence, privacy, truthfulness, and respect. We obtained the written informed consent of the participants, who knew the goals, the benefits, and scope of the research. To ensure the ethical principle of privacy, the names of the participants were replaced with fictitious names.

\section{RESULTS}

The student-nurse relationship: the core for the development of clinical practice was presented with the qualitative axis running through the data. And the pedagogical relationship 'there for the student' emerged as the target category or central thematic core. This kind of pedagogical relationship showed itself with the following dimensions or categories (see Table 1):

Table 1 - Qualitative axis, target category, and resultant categories. Barcelona, Spain, 2012

\begin{tabular}{|c|c|c|c|c|}
\hline Qualitative axis & Goal category & Definition & Category & $\mathbf{U M}^{*}$ \\
\hline \multirow{6}{*}{$\begin{array}{l}\text { Student-nurse re- } \\
\text { lationship: starting } \\
\text { nucleus for the de- } \\
\text { velopment of clinical } \\
\text { practice }\end{array}$} & \multirow{6}{*}{$\begin{array}{l}\text { Pedagogical relation- } \\
\text { ship between student } \\
\text { and tutor nurse who is } \\
\text { 'on the student's side' }\end{array}$} & \multirow{6}{*}{$\begin{array}{l}\text { Pedagogical practice between } \\
\text { student-nurse focused on } \\
\text { the student characterized by } \\
\text { qualities such as: monitoring, } \\
\text { trust, allow lack of knowl- } \\
\text { edge, allow mistakes, and } \\
\text { autonomy }\end{array}$} & $\begin{array}{l}\text { Student side-oriented: 'be- } \\
\text { ing on my side' }\end{array}$ & 38 \\
\hline & & & Trust: 'trust me' & 69 \\
\hline & & & 'offers their best' & 23 \\
\hline & & & $\begin{array}{l}\text { Autonomy: 'I'll be safer each } \\
\text { time' }\end{array}$ & 55 \\
\hline & & & Allow lack of knowledge & 14 \\
\hline & & & Allow mistakes & 14 \\
\hline
\end{tabular}

* Units of meaning 


\section{DISCUSSION}

We will now present the category analysis to show a polyphonic discourse between the participants' voices, the author' voices, and their own interpretations. The categories "allow the students to not know and make mistakes" were analyzed cross-sectionally when discussing the categories, particularly in the first category.

\section{Student-oriented: "is on my side"}

A relationship that is on the side of the student sees them as a person, as a protagonist of their own learning and their own experience, with recognition and trust, questioning those skills needed to: competently care for another person, develop reasoning and clinical skills and start a therapeutic, communicative, and ethical relationship with the patient. ${ }^{20}$ It's a relationship without an attitude that puts the student in a step below, with a look that infantilizes or that doesn't recognize the student with their skills and knowledge as a person. [...] I realized that I wasn't treated with superiority as if I didn't know anything (Interview with student 2).

This student's feeling that the nurse 'is on my side' arises from their realization about the interest that holds the nurse in their learning, teaching processes more often than disjointed activities, and in the establishment of a relationship characterized by recognition, the commitment, reciprocity, presence, and motivation, which agrees with the findings of Santos, et al. ${ }^{21}[\ldots]$ when I say she's on my side, I mean you see he is interested in me learning, Jordi [nurse] is teaching me the whole process from start to finish of a task, the whole routine, he explains everything to me. So, by explaining everything, I realize he's on my side, he's interested, and that, of course, makes me want to learn mode because you are already interested and notices that he feels the same way (Interview with student 1 ).

It is necessary to emphasize the impact that the tutor's committed attitude has on the student's motivation and confidence..$^{10}[. .$.$] it's like he needs me,$ because if it wasn't for me, surely he wouldn't be learning so much, because a person loses a little bit of interest if this wasn't a good environment, and there's more trust as time passes (Interview with student 1).

Being on the student's side means to know and to connect with the experience of being a student, paying attention to their own words and actions, to help recognize nursing care qualities, and to guide through a set of mimicry. ${ }^{5}[. .$.$] the student mimics your$ actions, so we need to be very careful with how we act or with what we say, because the student copies, if you are empathic then the student is empathic (Interview with tutor nurse).

All those traits of care can be obtained from the student's side fully, being experienced in action at one time, space, corporality, and interrelation..$^{10,22}$ The dialogue between student and nurse coincides with the essential characteristics mentioned by Schön: ${ }^{5}$ it takes place in the clinical context within the performance of student care activities, uses actions and words equally, and depends on a reflection of reciprocal action. [...] in some situations, for example, in the implementation of the protocol of parenteral nutrition, I confuse one step with another, but I'm lucky because I have my nurse on my side. When I have doubt, I ask him, and not only when I'm in front of him, I know that, when I'm indecisive, I can run to him and ask, because my greatest fear is to make a mistake that can cause damages (Student 3's reflective journal).

Here, we can appreciate, on the one hand, the dialogue between student and nurse as a particular form of call and response $\mathrm{e}^{10}$ and the freedom to ask; and, on the other, the nurse's monitoring and physical presence. ${ }^{21-22} \mathrm{Be}$ on the side of the student requires qualities such as good judgment and pedagogical tone. ${ }^{8}$ This is an essential pedagogical capability: knowing how to act with caution and accuracy in pedagogical situations, starting from a reflective character thoroughly wrought. ${ }^{13}[. .$.$] he$ always told me, 'instead of going this way, go that way, use this instead of that', but he said it politely, so that is very important, to do it always politely (Interview with student 3 ).

Being on the side of the student is a pedagogical aid relationship which involves student learning, allows the student to make mistakes and not know, it uses reflective strategies such as asking question and putting the student in the situation, and turns the student into a participant in the evaluation, care planning and further clinical evolution of the patient. [...] he counted on me. When I arrived, he told me the part, we listened to the part and he told me, 'You don't get, see! I'll explain it to you', e he asked me and made me think. With him, I knew what my patients had, what could go wrong, what could go right, what I had to do for them, what I didn't have to. Another thing that should be highlighted, was the bombardment of questions about drugs, suspected cases, techniques, which Carles [the nurse] made us do. This way of teaching made us the situation and we could learn all the skills and knowledge to solve it (Interview with student 3). 
The purpose of this student follow-up is the discovery and interpretation of reality; the tutor introduces the practical world, but that doesn't mean they become a copy of the tutor; the students must see with their own eyes, not with the tutors. The student can be a mediator, a mirror showing an image of the clinical tutoring practices that have to be reconsidered, challenged and updated. ${ }^{11}$ Therefore, the student in the clinical practicum adopts a role of protagonist in their training and their learning depends not only on the pedagogical relationship established with their tutor but also beyond their desire. ${ }^{23}$

\section{Trust: "trust me"}

It is important that the student feels they can trust in the professional world and in those who practice the profession, students who can consolidate this trust will be open to new experiences and will be able to practice new skills and learn from their mistakes. ${ }^{24}$ When the student makes the decision to let themselves be guided and to ask for help freely, this is when they start to trust their mentor, ${ }^{25}$ which, in this case, is the nurse. [...] to see that Charles trusted him, that generated trust, and also since he was an open person, any moment I had a question, because I wasn't scared, I wasn't embarrassed or ashamed to say, 'See, I don't know about that, see, this happens and what should I do?'. So that's something made me feel safe to do more and start doing because I was afraid, he already trusted me, so, because he already trusted me, I felt safer doing everything and he supported me (Interview with student 3 ).

This is what we could call a virtuous circle of trust: the nurse trusts the student and shows that trust; the student picks up on the trust that the nurse generates as a mirror; the student imitates the tutor's actions, imitates that trust, trusting each other and, on the other hand, he acquires trust and self-confidence to act autonomously. [...] I consider Anabel [nurse] to be the person who really taught me and who gave me the confidence to act freely. You feel that they teach you the theory really well in that unit, for what you're treating so then you know where you should focus. I believe that influences a lot, depending on your nurse and their way of teaching. As well as her patience and the freedom she gives you to do things and you can see she trusts you e gives you the freedom to act more freely (Interview with student 4).

Trusting the student implies knowing the student's capabilities and developments, favoring their autonomy, noting the problems they may find during their clinical performance and the various possibilities of action. And so, to delegate a student care action is perceived as a sign of trust and as an opportunity to carry out a development on their own. [...] in this case, because it lets you do something that is risky and if they are delegating something to you it is because they trust you, obviously, but she always shows me that every day, each time more, or if you realize that they're a little busy, they say, 'don't worry', which demonstrates they are on your side. That is also important to me, that they may give me free rein, it makes me trust myself. I like to be given a little freedom in this sense, so I can act and see how I can develop alone (Interview with student 2).

A mentoring practice that trusts the student is concerned with integrating the theoretical content taught in school with practice training, noting the problems the student may find during their clinical performance, teaching to solve the problems that arise and give the students safety and autonomy. [...] we take into consideration the basic theoretical aspects that they must know from school, [...] If they don't know, I try to explain the problems that may find when performing the technique, because not everything that is theoretical will always turn out the same, it is possible that they will find many problems or several problems and it is important to know how to do the technique well, how to make mistakes e how to solve all the little problems that come up. I try to explain how they'll do everything and, if something goes wrong, how to solve it. If I consider them to be able to do it, I let them do it alone so they can do it without any problems, if otherwise, I go and support them with my presence (Interview with tutor nurse).

Here we note that the nurse is linked with the experience of being a student and their vulnerability, therefore they try to maintain an empathetic and trusting relationship so that the student can develop without pressure, caring also for a safe clinical practice for the patient and for the student. [...] first trying to maintain an empathetic relationship with the student. For the student, everything is new, he doesn't know how to move around the hospital or unit, or how to get along with the team, nor with the teacher because they don't know the teacher beforehand and that's a person who will evaluate them and evaluate them continually, and the students know it. By giving them enough confidence to make them feel relaxed, not pressured, but watching, because we can't forget that we are dealing with people and certain mistakes can arise which may adversely affect those people, because trying to maintain this balance between giving this margin of confidence and on the other hand controlling the situation at all times so that there is no danger (Interview with tutor nurse). 


\section{"Offers their best"}

To 'be on the side of the student' is to be with a pedagogical intent and direct concern that the student's clinical experience complies with the criteria of continuity and interaction. ${ }^{26}[\ldots] I$ like to create weekly objectives so that the student has self-motivation. For example, this week we'll try to get to you do this and that, next week with what you've learned this week, because you will try to do this and this, and soon they treat the situation another way, it's not just spending six, seven hours at the hospital, trying to environmentally understand everything possible. No, however, something a little deeper than all of that (Interview with tutor nurse).

In one of the observations on the unit, the nurse tells the student the weekly objectives, considers the interaction between the external conditions of the environment (or objective conditions) and internal conditions of the student (their knowledge, abilities, and skills to care for another person). [...] Nurse: Alright, next week you will take a patient on your own, you'll be the nurse, will oversee the patient's care e next week you'll have two patients, and that will be an exercise to help you learn other aspects, such as: negotiating with the patient for the sedestation, the negotiation with the auxiliary for the collaboration. This week, as I told you yesterday, you will enhance the speed, gain agility and manage your own time and activities, to gain confidence (Student 1 observation).

And so, the responsibility of selecting objective conditions, that is to say, the social structure of clinical situations in which the student finds himself, carries a responsibility of understanding the needs and capacities of individuals who are learning at any given moment and to see in which direction the student experience goes. In this way, it is guaranteed that the student's experience will be educational. ${ }^{26}$ Delegating a care should imply a previous pedagogical work by the tutor, which ensures that the student will learn how and why it that patient needs that care. ${ }^{23}[\ldots]$ my goal is not to get rid of the task to leave them, but for them to grow as much as possible and try to be responsible under my supervision. Everything that comprises the entirety of being a nurse to a patient and to plan and administer medication, the care, family management and team management, the preparation of activities along with the auxiliary, the doctor's visit, the physical therapist, this is all important (Interview with tutor nurse).

For the student, this situation is experienced as a provocation, is a way to prove their own performance, and it generates motivation, development of an autonomous practice, responsibility in the care of another person and attention to their own practice.
[...] those who realize they can do it alone because we're giving them freedom, this is important as a test and to see if they can do it alone (Interview with student 1).

In the practice of prior tutoring, it is good to recognize the student as a person who educates and who has experiential knowledge. [...] I get carried away a little bit by the knowledge that they [students] bring and learn through the practices, according to their evolution, as we'll be planning the goals (Interview with tutor nurse).

For the nurses, to 'be on the student's side' is to offer (do their best) all they know and also to admit all they don't know. ${ }^{21}[$ [...] you have to be very much on their side, offering them everything you know and this includes many things, of course, they asked about their concerns, it makes them work harder (Interview with tutor nurse).

Being on the side of the student is to listen carefully to their concerns, reflect on these, offer an answer, take into consideration the need of another, ${ }^{25}$ it requires knowing yourself as an individual in training and during your professional life. ${ }^{11,21}[\ldots]$ when I go home, the questions that were made by Irene, I reflecting on whether I could have given something more than I did in that moment, and on the next day I explain it to her: Irene, what you asked me yesterday, I forgot to tell you, because of course, you don't remember everything nor is everything remembered at the time and it forces you to get up to date and to seek knowledge and work and this is very positive for us (Interview with tutor nurse).

\section{Autonomy: "I'm freer each time"}

The student needs to "confront this situation," feel their own autonomy and feel allowed to exercise their discretion according to their own arguments and reflections on the care. ${ }^{23}$ This allows you to assume the responsibility of taking care of someone else, pay more attention to your action, reflect on the action "what do I have to do?" and learn in an experiential manner. Significant learning starts with the individual's interest and desire to learn, is related to their own experiences, beliefs, and emotions, and has been developed reflexively by themselves. ${ }^{23}$ [...] it is a process, where I'll be increasingly freer, leaving you to do things more freely. At first, he was there $100 \%$ and soon he delegates the responsibility more and more, that's fine, because then when I'm alone and the whole time thinking, what should I do?, what's the next step and it's a good exercise to assimilate every thing (Interview with student 1).

This shows that the role of the teacher is to be a facilitator of learning and to build a relationship 
supported by dialogue, completeness, trust and respect for freedom. ${ }^{8-10,27}[$ [...] that makes me have to pay more attention, because I have to do it alone and I guess that is also a sign of trust, is a good sign that I'm already being left alone (Note from student 1 ); [...] there are times when I like to be alone to be tested, what would happen if I was given these people alone, if this were my responsibility (Interview with student 2).

To acquire more and more autonomy means that the student can address the clinical situation, address the problems and learn to solve them by themselves, reflect from inside the action, make deliberate and properly argued decisions about the benefits and losses of their action, acquire security in their performance and take responsibility for their execution. $^{22,28}$

The autonomy process will occur gradually and in accordance with the uniqueness of the student. The student learns to observe and imitate the nurses when interacting with patients and with other students. [...] in most cases, the student likes to go just because they like to face the provocations, and when there isn't a clear choice between going alone or going with me, I give them the option to go with a buddy, because they feel protected and because it is not the figure of the teacher who's watching, but the figure of a companion who, they have a question, they can ask him or her, and so it seems that they did it alone, is an intermediate step between 'are you coming with me or alone?' (Interview with tutor nurse).

For the student, to meet before their partner allows them to give an account of what he learned, recognize the autonomy gained in their practice and cultivate collaborative work. [...] I like it because I'm with a companion who is on my level, so I like it, it almost like I'm alone, but I also have help, or they have help, you realize you can do it on your own (Interview with student 2).

Therefore, the teaching and learning between pairs in practicum are as valuable as those that happen with the tutor. ${ }^{5,29}$ Some students at times play the role of tutor and it is precisely through a peer group that a student can enter fully into the world of practicum, learning new habits of thought and action.

Allowing the student to be a nurse and participate in the decision-making in patient care under the supervision of a tutor nurse is another of the strategies employed by the tutors to encourage student autonomy. [...] it makes you confident to say: well, today you do, for example, I had never changed a parenteral, because I thought, 'today I'll do it so you can see it, then next day you do it, I'll show it and then I let you do it alone', so when I do it the next day e she says, 'come, I'll see it' and that will give you confidence today: I'll do it well or I can do it well. It helped me a lot with what I said before, to have autonomy, to be me (Interview with student 5).

This practice that progresses to the autonomy of the student, enables the development of selfconfidence, responsibility, freedom, independence, autonomy, and security, as well as the preparation of clinical reasoning and decision-making.

This is how the teacher-student pedagogical relationship focused on the student shares key elements for an effective mentoring relationship, i.e. it is a relationship characterized by open communication, motivation, interpersonal care, mutual respect, trust, exchange of knowledge, collaboration, and the modeled. ${ }^{30}$

\section{CONCLUSIÓN}

Both in the pedagogical faculty-student relationship and in the nurse-patient therapeutic relationship, aspects of care such as presence, empathy, dialogue, disposition, trust, responsibility, autonomy, and the preservation of a person's dignity contribute to the establishment of ethical and humanizing relations. When the nurse 'is present', fully present with the person hospitalized and/or the student, the nurse transfers and connects with the other; this favors therapeutic and educational conscientious meetings with a dialogic, intersubjective, authentic, self-reflexive and aware character.

The pedagogical relationship that is on the student's side' offers their very best, is concerned with the student's learning experience, is participant in their mistakes and collaboratively teaches and learns to solve problems arising from the action, is aware of is said and done in the pedagogical action and of the effect of this action on the student's education and considers the practice of clinical tutoring as an opportunity to teach and learn at the same time. Is a pedagogical aid relationship that offers security, empowerment, trust, and freedom for the student to progress in their autonomous practice. It is focused on a concrete student experience and on the meanings constructed around the act of caring for someone else, rather than in abstract theorizing or mere troubleshooting. This is definitely a caregiving relationship that favors a humanizing pedagogy. The nurse who takes care of the student, teaches care by caring and, later, the student will care for the patient and as the nurse cared for the student.

Given the importance of the topic, it is necessary to deepen the theme around the experience 
of the student in his or hers interaction with the patient and how the care is perceived, learned, and practiced during clinical practice. A few questions that remain in this line of research are: How can the practice experiences give students opportunities to learn about and connect with patients? How are the student's contributions in the care of patients recognized or passed forward? What repercussions are there for student care and the care of hospitalized patients when the nurse's training consists of an authoritarian practice?

\section{ACKNOWLEDGEMENT}

We thank the National Universidad nacional de Colombia, the Administrative Department of Science, Technology and Innovation Colciencias of the Republic of Colombia. And the University of Barcelona and the University Hospital of Bellvitge for the support given to complete this work.

\section{REFERENCES}

1. Hernández JF. La enfermería frente al espejo: mitos y realidades. Documento de trabajo No. 162/2010. Fundación Alternativas; 2010 [cited 2015 Jul 01]. Available from: http:/ /www.fundacionalternativas. org/public/storage/laboratorio_documentos_ archivos/055a5e37064013682804231c1369b45e.pdf

2. Benner P, Sutphen M, Leonard V, Day L. Educating nurses. A call for radical transformation. United States of America: Jossey-Bass; 2010.

3. Queirós PJP. The knowledge of expert nurses and the practical-reflective rationality. Invest Educ Enferm. 2015; 33(1):83-91.

4. Medina JL. La pedagogía del cuidado: saberes y prácticas en la formación universitaria en enfermería. Barcelona (ES): Laertes S.A; 1999.

5. Schön D. La formación de profesionales reflexivos. Hacia un nuevo diseño de la formación y el aprendizaje en las profesiones. Madrid (ES): Paidós Ibérica S.A; 1992.

6. Dewey J. Cómo pensamos. Nueva exposición de la relación entre pensamiento reflexivo y proceso educativo. Barcelona (ES): Paidós Ibérica S.A.; 2007.

7. Diekelmann N. Curriculum revolution: a theoretical and philosophical mandate for change. En: National League for Nursing, editor. Curriculum revolution: mandate for change. New York, NY (US): Autor; 1988. p. 137-57.

8. Lima MM, Reibnitz KS, do Prado ML, Kloh D. Comprehensiveness as a pedagogical principle in nursing education. Texto Contexto Enferm [Internet]. 2013 Ene-Mar [cited 2016 Mar 17]; 22(1):106-13. Available from: http://dx.doi.org/10.1590/S010407072013000100013
9. Bardallo MD, Medina JL, Zabalegui A. Dialogic learning in the training of nurses. creative education [Internet]. 2013 [cited 2016 Aug 31]; 4(4):283-6. Available from: DOI:10.4236/ce.2013.44042

10. Paterson JG, Zderad LT. Enfermería humanística. México: Limusa; 1979.

11. Bardallo L, Rodríguez E, Chacón MD. La relación tutorial en el prácticum de enfermería. Rev Docencia Universitaria. [Internet]. 2012 [cited 2016 Jun 29]; 10(Esp):211-28. Available from: http:/ / eds.b.ebscohost. com/eds / detail/detail?sid=0785b800-b1a2-4d22b94d-ffac05004a26\%40sessionmgr120\&vid=0\&hid= 111\&bdata=JnNpdGU9ZWRzLWxpdmU\%3d\#AN= 90599605\&db=a9h

12. Solvoll B, Heggen KM. Teaching and learning care. Exploring nursing students' clinical practice. Nurse Educ Today. 2010; 30(1):73-7.

13. Van Manen M. Investigación educativa y experiencia vivida: ciencia humana para una pedagogía de la acción y la sensibilidad. Barcelona (ES): Idea Books; 2003.

14. Gadamer H. Verdad y método. $12^{\mathrm{a}}$ ed. Salamanca (ES): Sígueme; 2007.

15. Geertz C. La interpretación de las culturas. Barcelona (ES): Gedisa; 2012.

16. Goetz JP, LeCompte MD. Etnografía y diseño cualitativo en investigación educativa. Madrid (ES): Morata; 1998.

17. Strauss AL, Corbin J. Bases de la investigación cualitativa: técnicas y procedimientos para desarrollar la teoría fundamentada. Medellin (CO): Editorial Universidad de Antioquia; 2002.

18. World Medical Association. Declaración de Helsinki: principios éticos para las investigaciones médicas que involucran seres humanos. 59a Asamblea General. Seúl (KR); 2008 [cited 2010 Oct 15]. Available from: http:/ / www.isciii.es/ISCIII/es/contenidos/fdinvestigacion/fd-evaluacion/fd-evaluacion-eticainvestigacion/Declaracion-Helsinki-2013-Esp.pdf

19. España. Ley de Orgánica 15/1999 de 13 de diciembre de 1999: Protección de datos de carácter personal (LOPD). Boletín Oficial del Estado, núm. 298, 14 Dic 1999. p. 43088-99.

20. Salum NC, Prado ML. Continuing education in the development of competences in nurses. Texto Contexto Enferm [Internet]. 2014 Jun [cited 2016 Mar 17]; 23(2):301-8. Available from: http://dx.doi. org/10.1590/0104-070720140021600011

21. Santos MF, Merighi MA, Muñoz LA. La enfermera clínica y las relaciones con los estudiantes de enfermería: un estudio fenomenológico. Texto Contexto Enferm. [Internet]. 2010 Ene-Mar [cited 2016 Mar 17]; 19(1):112-9. Available from: http://dx.doi. org/10.1590/S0104-07072010000100013

22. Wilson AM. Mentoring student nurses and the educational use of self: a hermeneutic 
phenomenological study. Nurse Educ Today. 2014; 34(3):313-8.

23. Rodríguez M, Medina JL. El legado del cuidado como aprendizaje reflexivo. Rev Latino-Am Enfermagem [Internet]. 2016 [cited 2016 Aug 31]; 24: e2711. Available from: http://dx.doi.org/10.1590/15188345.0639.2711

24. Cohen HA. La enfermera y su identidad profesional. Barcelona (ES): Grijalbo; 1988.

25. Sennett R. El respeto: sobre la dignidad del hombre en un mundo de desigualdad. Barcelona (ES): Anagrama; 2003.

26. Dewey J. Experiencia y educación. Madrid (ES): Biblioteca Nueva; 2004.

27. Waterkemper R, do Prado ML, Medina JL, Schmidt, K. Development of critical attitude in fundamentals of professional care discipline: a case study. Nurse Educ Today. 2014; 34(4):581-5.

28. González CX. Formación del pensamiento reflexivo en estudiantes universitarios. Magis. Rev Inter Investigación Educ [Internet]. 2012 [cited 2015 Dec 20]; 4 (9):595-617. Available from: http://www.redalyc. org/articulo.oa?id=281022848005

29. Valencia MJ, García MLR, Lozano MM. Evaluación de las tutorías entre pares de la facultad de enfermería desde la perspectiva de los principales actores. Investigación Educativa Duranguense. [Internet]. 2013 [cited 2016 Aug 31]; 13: 7-11. Available from: https:/ / dialnet.unirioja.es/servlet/articulo?codigo $=4743344$

30. Eller LS, Lev EL, Feurer A. Key components of an effective mentoring relationship: a qualitative study. Nurse Educ Today. 2014; 34(5): 815-20. 